\title{
In good times and in bad: Die stormagtige verhouding tussen kerk en die orrel - is egskeiding onafwendbaar?
}

\author{
Author: \\ Ockie C. Vermeulen ${ }^{1}$ \\ Affiliation: \\ ${ }^{1}$ Department of Music, \\ North-West University, \\ Potchefstroom Campus, \\ South Africa \\ Correspondence to: \\ Ockert Vermeulen \\ Email: \\ ockie@ockievermeulen.com \\ Postal address: \\ Koekoekweg 1510, Waverley \\ 0186, South Africa \\ Dates: \\ Received: 07 Apr. 2014 \\ Accepted: 08 Jan. 2015 \\ Published: 28 May 2015 \\ How to cite this article: \\ Vermeulen, O.C., 2015, 'In \\ good times and in bad: Die \\ stormagtige verhouding \\ tussen kerk en die orrel - is \\ egskeiding onafwendbaar?', \\ Verbum et Ecclesia 36(1), \\ Art. \#1349, 11 pages. \\ http://dx.doi.org/10.4102/ \\ ve.v36i1.1349

\section{Copyright:} \\ (C) 2015. The Authors. \\ Licensee: AOSIS \\ OpenJournals. This work is \\ licensed under the Creative \\ Commons Attribution \\ License.
}

Read online:

Scan this QR code with your smart phone or mobile device to read online.
In good times and in bad: The tumultuous relationship between the church and the organ - is divorce inevitable? Through the ages, a delicate relationship has existed between the church and the pipe organ. Since the 10th century, the organ established itself as a unique instrument in service of worship. This relationship was not always a steady one, and this article investigates the tumultuous affair between the two parties. In part one of the article, which is a historic perspective, the relationship is discussed by looking at different cultures and uses of the organ in the worship service. This gives a sense of when and how the relationship came into being and developed or deteriorated. In part two, the current situation in the Afrikaans Reformed service is explored by conducting several unstructured interviews with key role players in the theological and musical world of South Africa. In part three, the study ventures into speculating about the future of the organ in the worship service by briefly looking at the attitude of the organist and spirituality of the postmodern church goer. In essence, this article reflects on whether the marriage between church and music instrument is solid or on its way to the divorce court.

Intradisciplinary and/or interdisciplinary implications: The relationship between organ and church has to be reconsidered. The use of the organ in the worship service has to be taken under scrutiny, and a new relationship agreement between the two partners has to be formulated.

\section{Vinjet 1}

Theuns $^{1}$ is die verpersoonliking van vandag se deursneëtiener. Soos die res van sy uitgebreide vriendekring, is hy dol oor rugby, die movies en om oor naweke saam met sy meisie uit te gaan.

Op sy iPod is daar musiek van Muse, Slipknot en selfs Die Heuwels Fantasties, om maar net 'n paar te noem. Sy akademiese prestasies is gemiddeld en hy wil graag eendag 'n prokureur word.

Op Sondagoggende gaan hy saam met sy ouers en jonger suster na die naaste Nederduitse Gereformeerde (NG) Kerk se erediens waar hy binnensmonds saam met die orrel sing. Dit is okay, maar hy sien meer uit na die aanddiens in die kerksaal waar hy lead guitar in die band speel.

'Dis nie dat ek nie van die orrel hou nie', sê hy, 'maar jinne, dude, is dit nie bietjie outyds nie?'

\section{Inleiding}

Die orrel en die kerk het deur die eeue heen hegte liturgiese 'vennote' geword. Vir hierdie huweliksmaats was dit egter nie liefde met die eerste oogopslag nie. Die kerk het lank die gebruik van musiekinstrumente in die erediens met agterdog bejeën, maar die orrel is desnieteenstaande in ongeveer die 19de eeu nC as kerkinstrument gevestig (Williams 1993c:54). Hierdie verhouding was ook nie sonder stampe en stote nie. 'n Mens lees by verskeie geleenthede in die kerkgeskiedenis van die stormagtige verhouding tussen die twee - soms so erg dat daar 'n tydelike skeiding 'tussen tafel en bed' was.

In Suid-Afrika word die orrel dikwels as 'outyds' of 'swaar' bestempel en beskryf as ' $n$ instrument wat nie meer die musieksmaak van die hedendaagse erediensganger bevredig nie. As orrelis en kerkmusikus is hierdie aantygings vir my kommerwekkend en daarom ag ek dit noodsaaklik om hierdie standpunte te ondersoek. Sodoende kan 'n gevolgtrekking oor die toekoms van die orrel in die erediens, en dan beslis nie noodwendig as eksklusiewe begeleidingsinstrument nie, gemaak word. 
In my navorsing kon ek geen bron (wat in die afgelope drie jaar gepubliseer is) opspoor wat oor die toekoms van die orrel in die Afrikaanse kerke besin nie. Kloppers (2002a, 2002b, 2003a, 2003b, 2003c, 2005) onderskei haarself as himnoloog en skryf produktief oor erediensvernuwing, maar beskou die orrel as eksklusiewe begeleidingsinstrument sonder om die hedendaagse erediensganger se gevoelens oor dié instrument aan te roer. Basson (1997) doen navorsing oor die liturgiese gebruik van die orrel in die NG Kerk, maar hierdie navorsing is reeds 17 jaar oud. Viljoen (1999) ondersoek die kerkliedkrisis in die NG Kerk teen die draai van die eeu, maar sonder om spesifieke klem op die orrel te plaas. Heunis (2008) se navorsing oor die gebruik van die orrel in die NG Kerke van Port Elizabeth is baie insiggewend en kan moontlik as 'n maatstaf van orrelgebruik in Suid-Afrika geëkstrapoleer word. Campbell (2013) doen navorsing oor die missionêre karakter van musiekbediening in die NG Kerk. In sy studie verwys hy daarna dat die tradisionele rol van die orrelis in die vorige eeu stelselmatig verander het en dat musiekbediening as't ware sakramenteel van aard is (Campbell 2013:194-196). Tydens die afronding van hierdie artikel het ek te hore gekom van Swanepoel (2014) se navorsing oor die effektiewe gebruik van die orrel in hedendaagse eredienste van die NG Kerk. Sy beplan om in die afsienbare toekoms die nuutste statistiek oor orrelgebruik te publiseer en ek sien met afwagting daarna uit. Oor die gebruik van kontemporêre musiek in die erediens bestaan daar etlike publikasies (byvoorbeeld Du Toit [1979], Jackson [2006], Serfontein [2005], Smit [2010], Viljoen [1999] en Janse van Rensburg [1995]), maar die rol van die orrel binne hierdie konteks word verwaarloos.

Die hoofnavorsingsvraag wat vir hierdie artikel geformuleer word, is die volgende: 'Wat kan aangaande die toekoms van die orrel in die kerk afgelei word deur na hulle stormagtige verhouding deur die eeue te kyk?' Om hierdie vraag sinvol te kan beantwoord, moet die volgende subvrae eers beantwoord word:

- Wat kan uit die geskiedenis geleer word aangaande die verhouding tussen die kerk en die orrel?

- Wat is die situasie in Suid-Afrika vandag?

- Kan die orrel verskillende musiekstyle akkommodeer en so die heterogene aard van die hedendaagse erediensganger se musieksmaak bevredig?

Hierdie vrae word beantwoord deur ' $n$ literatuurstudie (' $n$ historiese perspektief) te onderneem, ongestruktureerde onderhoude met orreliste, 'n predikant asook 'n jong kerklidmaat te voer en ondersoek na die gebruik van die orrel in musiekstyle van die 20ste en 21ste eeu in te stel. Hoewel hierdie artikel vanweë my betrokkenheid daarby op die gebruik van die orrel in die Afrikaanse gereformeerde erediens fokus, sal daar ook vanweë geskiedkundige implikasies na die Katolieke erediens verwys word. Hierdie artikel bou voort op navorsing waarmee ek reeds in my doktorale proefskrif begin het. ${ }^{2}$

2.Kyk na Vermeulen (2012b).

\section{Die orrel as liturgiese instrument}

Die eerste orrel is reeds in die derde eeu voor Christus deur Kitsebios, 'n Griekse ingenieur, ontwerp en die orrel word daarom as die oudste klawerbordinstrument beskou (Bennet 1985:5). Die presiese wyse waarop die orrel sigself omstreeks $900 \mathrm{nC}$ as ' $\mathrm{n}$ kerkinstrument in Wes-Europa gevestig het, bly egter steeds 'n misterie (Williams 1980:34).

Williams (1966, 1980, 1993a, 1993b, 1993c) publiseer etlike bronne oor bogenoemde onderwerp. In The organ in Western Culture bied hy (William 1993b:1-16, 361-379) verskeie hipoteses aan om te verklaar hoe die orrel as kerkinstrument aanvaar is. Ander navorsers op hierdie gebied (soos o.a. Ingelse et al. 1995) ignoreer die onderwerp blatant. In die afdeling Het orgel als kerkelijk instrument (ibid:55-56) word die orrel in die Middeleeue kortliks bespreek, sonder om te verwys na die aanvaardingsproses in die kerk, voordat daar na die orrel van die 16de eeu aanbeweeg word.

Bewyse en akkurate bronverwysings uit daardie tydperk bevat te min inligting oor die onderwerp en enige navorser kan hoogstens afleidings maak en hipoteses formuleer (Williams 1993b:361). Die meeste navorsers is van mening dat die orrel die enigste akoestiese instrument was wat in staat was om genoegsame klank in die groot kerkruimtes te produseer. Sommige van hulle verwys selfs na die Vulgaat se regverdiging vir die gebruik van die orrel in Psalm 150:4: 'laudate eum in tympano et choro laudate eum in cordis et organo' $^{3}$ (Higginbottom 1998:130).

\section{Die orrel in die Middeleeue}

In geskrifte van die 10de eeu is daar spesifieke verwysing na die groot orrel in Winchester. Hierdie indrukwekkende instrument het oor nagenoeg 400 pype, verskeie blaasbalke (wat deur 70 mans aangedryf moes word) en twee klawerborde beskik en kon blykbaar myle ver gehoor word (Bennet 1985:5).

Die Middeleeuse orrel het in verskeie groottes voorgekom. Die kerkorrel (soos dié van Winchester) het waarskynlik oor baie swaar klaweraksies beskik wat moontlik met die vuis (in plaas van die vinger) geslaan moes word. Die positief was 'n kleiner orreltjie wat op 'n tafel geplaas kon word. Dit is deur een persoon bespeel en die blaasbalkie is deur 'n ander persoon beheer (Figuur 1). Die portatief was die kleinste tipe orreltjie en is deur een persoon bespeel (Figuur 2). Dit is dikwels op die skoot geplaas. Een hand het die blaasbalkie gepomp en die ander het die klawers bespeel (Yudkin 1989:448-450). Interessant genoeg word Dawid vanaf die 13e eeu in die ikonografie met 'n portatief op sy skoot in plaas van die harp uitgebeeld (Rumsey 1978).

Hierdie orrels is nie gebruik om die gemeentesang te begelei nie, maar eerder as 'n respons op strofes wat deur die priesters of koor gesing is (McKinnon 1998:3-20). Die gebruik om sang

3.In die Afrikaanse vertaling van 1983 word dit egter met ... prys Hom met snaarinstrumente en fluite' vertaal. 


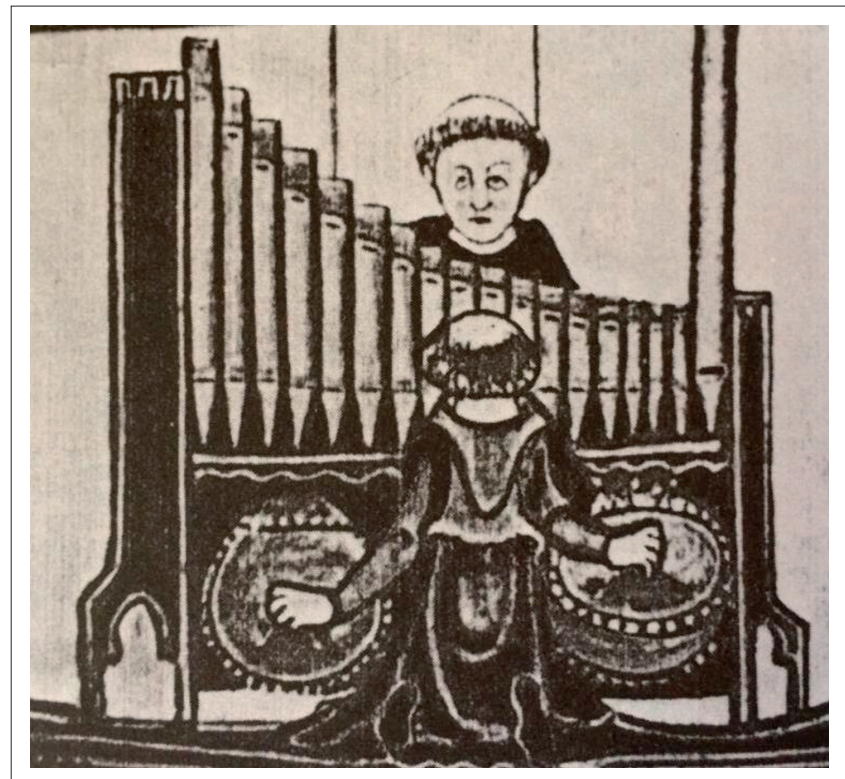

Bron: Yudkin, J., 1989, Music in Medieval Europe, Prentice Hall, New Jersey, p. 452 FIGUUR 1: Twee monnike bespeel die positief. Die naaste een beheer die blaasbalke.

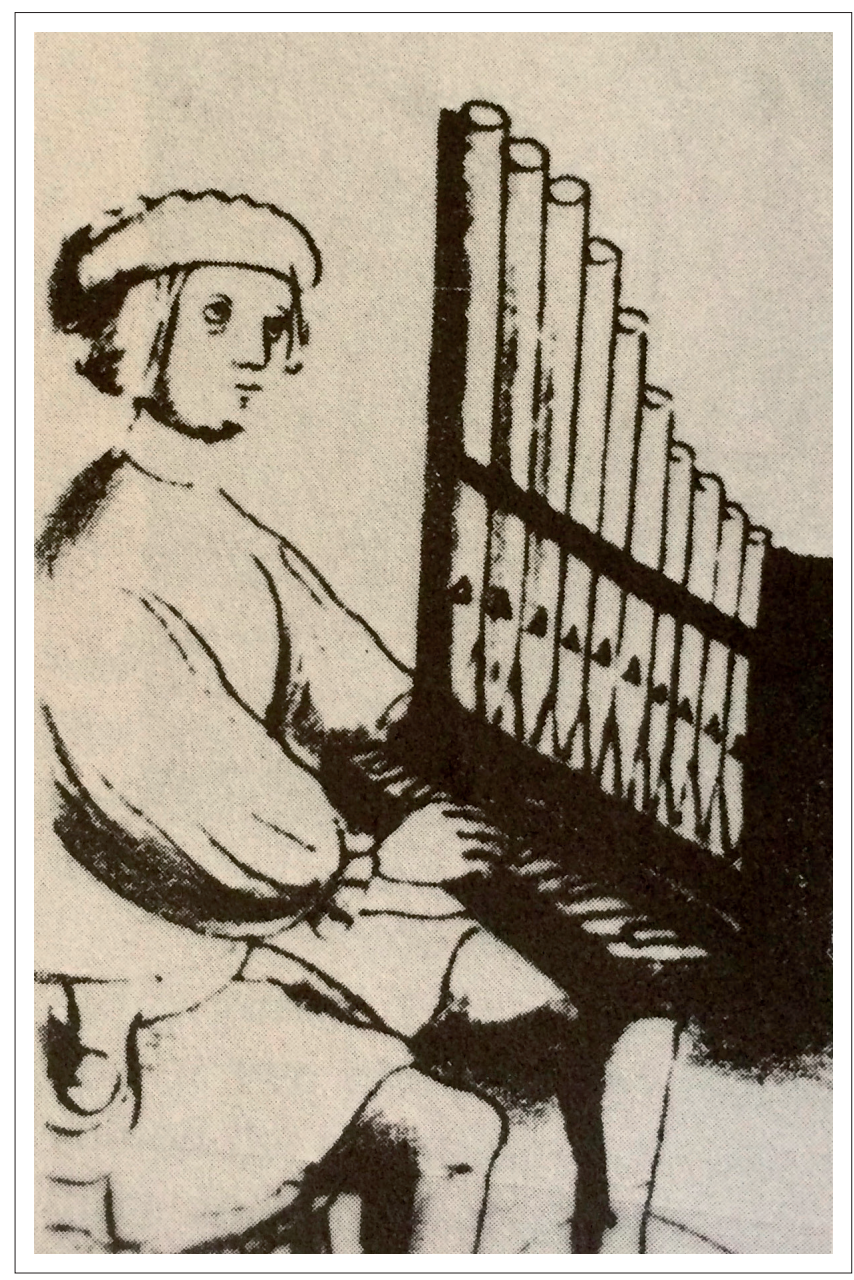

Bron: Yudkin, J., 1989, Music in Medieval Europe, Prentice Hall, New Jersey, p. 452 FIGUUR 2: Die portatief op die knieë.

met instrumentale musiek af te wissel, of die alternim praxis, het in die Middeleeue in die Katolieke erediens ontwikkel en tot vroeg in die 20ste eeu voortgeleef. Nie alleen het dit die liturgie versier nie, maar ook die volledige liturgiese tekste tussen resitasies en orrelspel verdeel (Higginbottom 1998:132-133).

\section{Die orrel vanaf die Reformasie tot die 18de eeu}

Vervolgens 'n kort beskrywing van die orrel as liturgiese instrument in verskeie dele van Europa.

\section{Engeland}

Die alternatim praxis is toegepas: In gesange sou die orrel die onewe verse speel wat die toonhoogte vir die sangstemme vir die daaropvolgende vers sou verskaf. Die orrel sou heel waarskynlik deur iemand bespeel word wat van kindsbeen af in die kuns van improvisasie opgelei is en met die kantillering bekend was. Later is 'n spesialis aangestel wat finansieel deur die kerk vergoed is (Gwynn 2003:74). In die tweede helfte van die $16 \mathrm{de}$ eeu en aan die begin van die $17 \mathrm{de}$ eeu het die Engelse orrel onstuimige tye tegemoet gegaan (meer aandag sal later hieraan gegee word), maar beleef teen 1660 weer 'n oplewing (Long 1971:230).

Die bekende Engelse voluntary, wat as naspel tot die erediens gespeel is, ontwikkel in hierdie tydperk. Solo-stop voluntaries is dikwels tydens Oggendgebede (Matins) op die kenmerkende prestantregister van die Engelse orrel uitgevoer (Ritchie \& Stauffer 1992:288).

\section{Nederland}

Tydens die Sinode van Dordrecht (1547) is daar besluit om orrelspel tydens die erediens af te skaf en die volgende drie redes is aangevoer (Ingelse et al. 1995:55):

- Orrelspel is vergelyk met die spreek van ongewone tale en klanke as gevolg van die musiek se kompleksiteit. 1 Korintiërs 14:194 is dus geïnterpreteer as 'n Skrifgebaseerde verbod op die gebruik van die orrel tydens die erediens.

- Die uitgebreide orrelnaspele kon daartoe lei dat die boodskap of preek vergeet word.

- As gevolg van hierdie naspele moes die dankoffer tydens die erediens opgeneem word en dit het 'n steurnis in die vloei van die liturgie veroorsaak.

Was dit nie vir die feit dat kerke op daardie stadium nog afhanklik was van die owerheid nie, het die Sinode alle orrels uit kerke verwyder. Gelukkig is hierdie 'staatseiendom' deur die owerheid beskerm (Ingelse et al. 1995:56). Die alternim praxis is ook hier toegepas want orrelbegeleiding vir gemeentesang is eers in 1632 volgens ' $n$ sinodebesluit goedgekeur. Manualitêre tussenspele is tussen versreëls ingevoeg en sodra die pedaalparty gespeel is, was dit die aanduiding vir die gemeente om die volgende reël te sing. Beskrywings van gemeentesang in Nederland in die 18e en 19e eeu is egter meestal negatief (Ingelse et al. 1995:56-58).

4.Volgens die 1983-vertaling: 'Maar in die byeenkoms van die gemeente wil ek liewe vyf woorde met my verstand praat om ook ander te onderrig as duisend woorde in ongewone tale of klanke.' 
Die orrelis moes oor die vermoë beskik om te kan improviseer asook om besyferde baslyne as begeleiding vir die koraalmelodie te realiseer. Hulle is verder voorgeskryf om statige en stigtelike musiek te speel in plaas van ligsinnige motette (Blume 1974:570).

Die orrel as konsertinstrument neem toe in populariteit en berigte lui dat Sweelinck in Amsterdam daagliks orreluitvoerings aangebied het tot vermaak van groot gehore (Ritchie \& Stauffer 1992:268).

\section{Frankryk}

Die Franse klassieke orrelmusiek, soos gebruik in die Katolieke erediens van hierdie tydperk, word vandag steeds as standaardrepertoire vir orreluitvoerings beskou. Die Franse klassieke orrel het oor unieke klankkleure beskik en is volgens musiekgenre gestandaardiseer. Die orrelis was uiters bedrewe as improvisator en die erediens is ryklik met orrelmusiek ingekleur. Dit kan in alle opsigte as ' $n$ hoogtepunt in die geskiedenis van Franse orrelmusiek beskou word. Gemeentesang, egter, was nie in hierdie eredienste baie prominent nie (Higginbottom 1998:140-141).

Calvyn kritiseer die gebruik van instrumentale musiek in die erediens. Volgens hom moes musiek direk aan 'n teologiese teks gekoppel gewees het en dit moes verder ook vir die gemeente verstaanbaar gewees het. Gevolglik was onbegeleide, eenstemmige sang die standaard in die Protestantse erediens (Blume 1974:517).

\section{Duitsland}

In die Lutherse erediens was dit reeds so vroeg as 1601 duidelik dat die orrel gebruik is om gemeentesang te begelei om sodoende die gemeente te help om saam op die regte toonhoogte te sing. Herl (2004) verwoord dit soos volg:

Gott sei gelobet und gebedeiet and ... Jesus Christus, unser Heiland, in their entirety shall be sung and simultaneously played on the organ. Thereby the common man, inexperienced in reading, may be awakened to thanksgiving. (bl. 132)

Die Duitse orrels uit hierdie tydperk na die Reformasie getuig van uitnemende vakmanskap en musiek is vir óf die Lutherse (Noord-Duitsland) óf Katolieke (Suid-Duitsland) erediens gekomponeer (Higginbottom 1998:142).

Alternim praxis was hier ook steeds in gebruik, alhoewel die rol van die orrelis as begeleier van die gemeentesang toenemend belangriker geword het. Substansiële komposisies (die sogenaamde koraalpreludes) het as inleiding tot die koraal gedien. Preludes, Fugas en Toccatas is bes moontlik in die erediens en konserte gebruik (Higginbottom 1998:142-143).

Die volgende (volgens J.S. Bach in 1720) is ' $n$ bewys van die uitgebreide rol wat die orrelis in die Lutherse erediens gespeel het (Ritchie \& Stauffer 1992:266-267):
- Voor die openingsmotet speel die orrelis 'n prelude.

- 'n Koraalvoorspel, wat op die Kyrie gebaseer is, word daarna gespeel.

- 'n Koraalvoorspel op die koraal wat voor die Evangelielesing gesing word, word gespeel.

- 'n Prelude word voor die weeklikse kantate gespeel.

- 'n Koraalvoorspel op die Credo (Wir glauben all' an einen Gott) word gespeel.

- 'n Koraalvoorspel op die koraal wat na die preek gesing word, word gespeel.

- 'n Prelude word tydens die nagmaal gespeel.

- 'n Prelude op korale wat reeds gesing is, word gespeel indien dit nodig sou wees.

In Arnstadt is Bach aangespreek oor die vreemde harmonisasies wat hy gebruik het om die gemeentesang te begelei. Hierdie getuienis is dus 'n aanduiding dat die orrel wel gebruik is om gemeentesang te begelei, alhoewel dit in sommige gemeentes steeds nie die geval was nie (Williams 2003:454). Die alternim praxis lei tot stelle variasies (soos die komposisies van Georg Böhm [1661-1733]) wat as tussenspele tussen verse van korale gebruik is (Ritchie \& Stauffer 1992:266-267). Die Noord-Duitse orreliste lewer gereelde orreluitvoerings wat getuig van die populariteit van die orrel as konsertinstrument (Ritchie \& Stauffer 1992:268).

\section{Italië}

Repertoire is hoofsaaklik vir gebruik in die Katolieke erediens gekomponeer en die pligte van die orrelis tydens die Sondagmis is soos volg deur Frescobaldi beskryf (Ritchie \& Stauffer 1992:281-282):

- Voor die Mis: Die orrelis speel 'n toccata. ${ }^{5}$

- Gedurende die Kyrie: Die orrelis speel 'n verset. ${ }^{6}$

- Ná die Epistel: Die orrelis speel 'n canzona. ${ }^{7}$

- Tydens Offertorium: Die orrelis speel 'n ricercar. ${ }^{8}$

Dit word soms deur 'n toccata voorafgegaan.

- Tydens die Elevasie: Die orrelis speel 'n stadige en uitdrukkingsvolle toccata.

- Ná die Nagmaal: Die orrelis speel 'n canzona.

Die gebruik van die orrel in die Katolieke erediens is reeds duidelik deur Pous Clemens VIII (Rome, 1600) gestipuleer (Ponsford 2011):

At the solemn Mass, the organ is played alternatim for the Kyrie eleison and the Gloria in excelsis ... ; likewise at the end of the Epistle and at the Offertory; for the Sanctus, alternatim; then more gravely and softly during the Elevation of the Most Holy Sacrament; for the Agnus Dei, alternatim, and at the verse before the post-Communion prayer; also at the end of the Mass. (p. 13)

5.'n Virtuose komposisie, met of sonder nabootsing, in 'n vrye en briljante styl (Kennedy 1996:739).

6.'n Kort orrelkomposisie wat as interlude of tussenspel dien, gewoonlik in ' $n$ nabootsende styl (Kennedy 1996:764).

7.'n Instrumentale komposisie in seksies wat van nabootsing gebruik maak (Kennedy 1996:123)

8.'n Instrumentale komposisie wat as voorloper van die fuga geag word en waarin ' $n$ tema in ander stemme nageboots word (Kennedy 1996:605). 


\section{Suid-Afrika}

Na die aankoms van Van Riebeeck in 1652 was daar vir die 154 jaar van Nederlandse bewind, vanweë heersende primitiewe en moeilike toestande, feitlik geen oprigting van pyporrels in Suid-Afrika nie. Ook was daar nie 'n groot behoefte aan pyporrels nie aangesien daar oorwegend van harmoniums ${ }^{9}$ en voorsangers in gemeentes gebruik gemaak is (Troskie 1992:1). Hoewel Nederland die goue eeu van orrelbou in hierdie tydperk beleef het, het alle pogings om orrels daarvandaan in te voer, misluk (Troskie 2010:x). Klein orreltjies wat wel in hierdie tydperk (soos die een vir Drakenstein-gemeente in Paarl in 1791) gebou is, het nie behoue gebly nie (Troskie 2013:84).

\section{Die orrel in die 19de en 20ste eeu}

As konsertinstrument is die orrel 'n populêre instrument in 19de-eeuse Engeland. Stelselmatig vervlak die repertoire tot transkripsies van bekende opera-arias en orkeswerke. Met die aanbreek van die 20ste eeu word die orrel in die kerk slegs gebruik om die gemeentesang te begelei en 'musiekvullers' tussen liturgiese handelinge te verskaf (Long 1971:337, 406).

Omdat die uitgebreide interludes tussen versreëls die gemeentes in Nederland meestal verwar het, het dié gebruik afgeneem, maar die gemeentesang word steeds deur die orrel begelei (Ingelse et al. 1995:60-62).

Die groot aantal gewyde orrelkomposisies wat die lig in Duitsland gesien het, is as 'n vervlakking in die kerkmusiek beskou. Feder (1974:371) wys op verdere vervlakking in hierdie tydperk: Die orrelis as professionele musikus het se prestige het afgeneem, in kuns is die klem op emosie geplaas in plaas van op vakmanskap, maklike singbare melodieë het voorkeur geniet en die invloed van die orkes het 'n negatiewe invloed op die ontwikkeling van nuwe instrumente gehad.

Die orrel het ' $n$ bloeitydperk in Frankryk beleef. Die alternim praxis het steeds in die erediens voorgekom en sekulêre sonate-bewegings is soms in afwisseling met vokale musiek gebruik. Dit het aanleiding gegee tot die sentiment dat die erediens oor die karakter van 'n orreluitvoering beskik het (Ochse 1994:127-128).

Vanaf 1806, die Britse besetting van die Kaap, ontstaan 'n nuwe era in die orrelbou in Suid-Afrika. As gevolg van die vinnige bevolkingsgroei deur wit setlaars in die land, die industriële ontwaking en die aktiewe rol van Britse, Duitse en Nederlandse sendingwerkers neem die vraag na orrels toe (Troskie 2010:x). Tot en met 1949 is nagenoeg 95\% van alle orrels in Suid-Afrika uit Europa ingevoer, enkeles uit Amerika en die oorblywende 5\% is deur Suid-Afrikaanse orrelbouers gebou (Troskie 2013:84). Teen 1950 het feitlik alle gereformeerde kerke in Suid-Afrika oor 'n orrel beskik en Troskie (2013:87-90) is van mening dat dit juis die orrel was

9.Kleiner, draagbare klawerbordinstrumente. Twee pedale, wat die speler met sy twee voete alterneer, veroorsaak dat die blaasbalke wind voorsien wat nodig is om twee voete alterneer, veroorsaak dat die blaasbalke wind vo instrumente te produseer (Kennedy 1996:331).
klank instrus wat nie alleen die kerkmusiektradisie in Suid-Afrika gevestig het nie, maar ook die draers van die Westerse musiekkultuur was. Die orrel speel ook 'n groot rol in die musiektradisie van die Nuwe Apostoliese Kerk, die Congregational Church en die Morawiese Kerk, maar minder in die swart kerke (Troskie 2013:90). Tot en met die 1980's was die orrel die eksklusiewe kerkinstrument in die Afrikaanse gereformeerde kerke en dit het nie net die gemeentesang begelei nie, maar alle liturgiese musiek verskaf (Kruger 2007:18).

\section{Die orrel verval in onbruik: Enkele voorbeelde}

Die verhouding tussen kerk en orrel het soms, tydelik, verbrokkel. Enkele voorbeelde word vervolgens kortliks bespreek.

\section{Die Reformasie}

Vir Zwingli en Calvyn was dit baie belangrik om met ongeregverdigde gebruike in die erediens te breek en albei was agterdogtig teenoor die gebruik van musiek in die erediens. Veral Zwingli het alle musiek verban, gevolglik ook die orrel. Hierdie verbod op musiek het tot die vernietiging en verkoop van baie kerkorrels gelei - soveel so dat die orrel in Switserland vir bykans 20 jaar lank stilgemaak is. Gemeentes het eers aan die einde van die 16de eeu stelselmatig weer begin sing (Blume 1974:510).

Die gevolge van Zwingli se Reformasie het gou na Duitssprekende Switserland versprei. Sy verbod op musiek in die erediens het tot die vernietiging en verkoop van kerkorrels gelei. Ook hier het gemeentes eers aan die einde van die 16de eeu weer stelselmatig begin sing (Blume 1974:513).

\section{Engeland: 1640}

Die Puriteine het min deernis met die orrel gehad. Hulle het oorreageer teen die ryk versierde Roomse-Katolieke katedrale en eredienste en het onskatbare kunswerke en orrels vernietig. Enige iets wat moontlik die gemeente se aandag van God se Woord kon aflei, is verwoes (Long 1971:204).

Die vernietiging van die orrel in Chichester Katedraal word soos volg deur Ryves (1685) beskryf:

$[T]$ he Commanders having in person executed the covetous part of Sacrilege, they leave the destructive and spoyling part to be finished by the Common Soldiers: brake down the Organs, and dashing the Pipes with their Pole-axis, scoffingly said, hark how the Organs go (p. 139)

Skielik het orreliste, kerkmusici en koorsangers hulle sonder werk bevind en is hulle gedwing om die kerk te verlaat op soek na 'n ander bron van inkomste (Long 1971:207). Omdat die kerk op daardie stadium die beste musici in diens gehad het, het kerkmusiek in Engeland onberekenbare skade gelei toe hulle 'n ander heenkome buite die kerk moes gaan soek het (Long 1971:207). 
Hierdie destruktiewe tydperk het in 1660 met die troonbestyging van Charles II tot ' $n$ einde gekom. Die koor en orrel het gaandeweg weer hul regmatige plek in die erediens ingeneem (Long 1971:211).

\section{Frankryk ca. 1789}

Tydens die Franse rewolusie is die stadslewe onderbreek, kerke bestorm en orrels vernietig om sodoende patrone uit die pype te vervaardig. Dit het 'n demper van ongeveer 'n halfeeu op die ontwikkeling van Franse orrels en orrelrepertoire geplaas (Williams \& Owen 1980:109-110). Min van die oorspronklike klassieke orrels het oorleef en hulle is meestal deur romantiese instrumente van die 19e eeu vervang (Ritchie \& Stauffer 1992:275).

\section{Gevolgtrekkings rondom die historiese perspektief}

Deur die eeue heen bewys die orrel sigself as bruikbare kerkinstrument. Dit is aanvanklik met vrug in erediens gebruik, maar is in die vroeë gereformeerde kerk eers met agterdog bejeën. As gevolg van 'n ongegronde oorreaksie teen bestaande gebruike en praktyke verval die orrel tydelik in onbruik. Stelselmatig besef die kerk wel weer die nut van musiek asook die belangrikheid van die orrel in die erediens. Laasgenoemde word veral toegeskryf aan die orrel se inherente vermoë om massasang te begelei. Dit is nodig om waar te neem hoe orrel- en kerkmusiek voortdurend aangepas het by die kultuur en populêre musiekstyl van die dag, vanaf die Middeleeuse kantillering tot die gebruik van sekulêre romantiese orrelsonates in die Franse erediens.

Suid-Afrika het sedert die 19de eeu 'n bloeitydperk in die vestiging van 'n eie orrelkultuur beleef. In baie kerke (verál die Afrikaanse gereformeerde kerke) word die orrel vanaf die 1950's die eksklusiewe kerkinstrument.

Hier is dus 'n duidelike, globaal historiese neiging sigbaar: Dit neem 'n redelike tydjie vir die kerk om die orrel deel van die erediens te maak. Wanneer die nut van die orrel as liturgiese instrument besef word, word dit met vrug en doeltreffendheid in die erediens aangewend. Dit bly egter nie onveranderd so nie. In die volgende afdeling gaan ek in besonderhede hierop in.

\section{Die situasie in Suid-Afrika vandag}

Die volgende afdeling is 'n opsomming van en kommentaar op 'n ongestruktureerde onderhoud wat in November 2013 met prof. Daleen Kruger te Potchefstroom gevoer is. Sy is 'n orrelis, kerkmusikus en musikoloog en is aan die NoordwesUniversiteit verbonde. Soortgelyke onderhoude is ook in Januarie 2014 met prof. Gerrit Olivier ('n gerekende orrelis, komponis, musikoloog en kerkmusikus), dr Marina Strydom (leraar van die NG Kerk Pretoria-Oos) en Theuns ${ }^{10}$ ('n 16-jarige gemeentelid) gevoer.

10. Kyk na voetnota 1.
Teen die 1950's was die pyporrel reeds as die eksklusiewe kerkinstrument in die meeste gereformeerde kerke in Suid-Afrika gevestig, veral in die sogenaamde drie Susterskerke, naamlik die Nederduitse Gereformeerde Kerk, die Nederduitsch Hervormde Kerk van Afrika en die gereformeerde kerke in Suid-Afrika. Inteendeel, die Afrikaanse erediens was sinoniem met orrelbegeleiding. Die orrelis was alleen verantwoordelik vir die musikale inkleding van die erediens en daar is slegs uit amptelike liedbundels gesing.

In 1980 het prof. Albert Troskie die Suider-Afrikaanse Kerkorrelistevereniging (SAKOV), wat na die belange van die kerkorrelis omgesien het, gestig, maar slegs 'n dekade later het die prentjie in die Afrikaanse gereformeerde kerke aansienlik verander. Nuwe strominge het binne die kerkmusiekkringe ontwikkel en daar was al hoe meer teenkanting teen die orrel as eksklusiewe kerkinstrument. Die worship-band of kerk-orkes het meer aanklank gevind en is meestal tydens die aand-eredienste as alternatief tot orrelbegeleiding verkies.

Dit het sedert die 1980's tot die sogenaamde worship wars gelei. Die soeke na die geskikste kerkmusiekstyl het groot debatte en tweespalt ontketen omdat belangegroepe sekere musiekstyle meer geskik as ander vir gebruik in die erediens geag het.

Gelukkig lyk dit asof teoloë en musici uit verskillende agtergronde vandag saam kan besin en besluit oor die toekoms van erediensmusiek, individuele voorkeure ten spyt.

Kruger (pers. komm., November 2013) is van mening dat die orrel nie vandag meer vanselfsprekend as eksklusiewe kerkinstrument geag kan word nie. 'n Oudtydse en argaïese benadering tot die gebruik en aanwending daarvan gaan net tot ' $n$ verdere afname in die vraag na hierdie veelsydige instrument lei.

Die aanbiddingstyle waarin die orrel gebruik word, asook die spiritualiteit waartoe dit spreek, word dikwels gestereotipeer en meestal as 'tradisioneel' of 'konserwatief' bestempel (Strydom pers. komm., Januarie 2014).

\section{'n Afname in populariteit}

Alhoewel Theuns (pers. komm., Januarie 2014) soms saam met sy ouers na klassieke musiekkonserte toe gaan, was hy nog nooit by ' $n$ orreluitvoering nie en is hy ook nie van plan om binnekort een by te woon nie: 'Ek sal nie vir 'n uur lank na Dracula-musiek kan luister nie.' Dit wil voorkom asof die orrel nie meer so gewild is by musiekstudente, konsertgehore en kerklidmate as 'n paar jaar gelede nie (Viljoen ${ }^{11}$ 2014) en daar bestaan 'n paar moontlike redes hiervoor.

11.Wim Viljoen is tans die hoof van die Departement Musiek aan die Universiteit van Pretoria. 


\section{'n Afname in die hoeveelheid klavierstudente}

Die jong klassieke musikant verkies om 'n orkesinstrument te bespeel. Die gevolglike afname in potensiële klavierstudente lei tot 'n proporsionele afname in orrelstudente op tersiêre vlak (Viljoen 2014). Studies in jazz of kontemporêre musiek is ook deesdae gewilder en dit beteken dat instrumente soos die saksofoon, tromme of die kitaar groter leerlinggetalle lok (Kruger pers. komm., November 2013).

\section{'n Koste-implikasie}

Die potensiële inkomste van kerkmusici is baie laag en vergelyk nie met die groot uitgawes wat tersiêre studie vereis nie. Die koste gekoppel aan orrellesse en -studie weeg nie op teen die gemiddelde salaris wat die orrelis verdien nie (Olivier 2014).

\section{Die aanpassingstryd van orreliste}

Sommige orreliste is hardkoppig en weier om ' $n$ aanpassing in hulle spel of repertoirekeuse te maak om sodoende die veelsydigheid van die instrument te illustreer en daarmee die uiteenlopende smake van die erediensgangers te akkommodeer. Sommige orreliste beskik eenvoudig nie oor die ervaring of vermoë nie. Hierdie orreliste kan dus nie in uiteenlopende musiekstyle funksioneer nie en dit beïnvloed die aanvraag na die orrel negatief (Kruger pers. komm., November 2013). Dit wil voorkom asof sommige orreliste rigied is in hulle benadering, terwyl dit noodsaaklik is dat hulle bereid moet wees om eerder met ander musiekstyle te waag as om slegs met die suiwer klassieke styl te eksperimenteer. Waagmoed is dus hier die wagwoord. In Suid-Afrika is daar enkele voorbeelde waar orreliste daarin slaag om die orrel 'n vars, kontemporêre klank te gee (Strydom pers. komm., Januarie 2014). Olivier (2014) is van mening dat die leerinhoud van die kursusse in kerkmusiek hierdie probleem effektiewer sal moet aanspreek. Opleiding vir orreliste in kontemporêre musiek sal 'n aanwins wees (Heunis 2008:58).

\section{'n Tekort aan gekwalifiseerde orreliste}

Die tekort aan gekwalifiseerde orreliste word groter. Kerke beskik dikwels nie oor fondse om hulle musici te ondersteun met die aanskaf van bladmusiek, bywoning van kursusse of voltydse indiensname nie (Kruger pers. komm., November 2013). Dieselfde geld vir die opleiding van toekomstige dominees: Himnologie is deesdae net 'n keusevak en predikante word gelegitimeer sonder substansiële kennis van kerkmusiek of -liedere (Olivier 2014; Strydom pers. komm., Januarie 2014).

\section{Swak instrumente in swak akoestiese ruimtes}

In Suid-Afrika is daar ongelukkig heelwat swak orrels wat in ongunstige akoestiese ruimtes staan. Klein orreltjies sonder die nodige krag en klankkleurverskeidenheid sal nooit die geïnspireerde samesangbegeleiding van 'n groot gemeente effektief kan hanteer nie (Kruger pers. komm., November 2013). Oor die algemeen ontbreek dié orrels grondregisters en 'n forse pedaalklank wat onontbeerlik vir die begeleiding van gemeentesang is (Olivier 2014).

\section{Geestesvervlakking in die samelewing}

Die algemene gees van geestesvervlakking en sekularisasie het die Afrikaanse gereformeerde kerk bereik. Die erediensganger wil vermaak word en dit word gereflekteer in die keuse van liedere wat in die erediens gesing word. Die merkbare voorkeur na die 'luisterliedjie'-liedtipes, wat meer vir klein groepe as vir 'n gemeente geskik is, dui daarop dat die hedendaagse erediensganger slegs vermaak wil word (Olivier 2014). Dit is ook sigbaar in die beoefening van spiritualiteit en kulturaliteit: As gevolg van 'n soeke na vastigheid en absolute sekerheid in 'n onsekere wêreld is mense opvallend bang om met die diep misterie in hulle eie binne-wêreld en met die onverstaanbare misterie van God te konnekteer. Dit word in maklik verteerbare teologie verklank en word dikwels in die meeste kontemporêre musiekbedieninge weerspieël (Strydom pers. komm., Januarie 2014).

\section{Postmodernisme}

Hoewel die begrip postmodernisme vanweë akademici se uiteenlopende interpretasies daarvan uit die staanspoor problematies was, som Butt (2006:10) dit op as 'n benaderingswyse waarin voorheen aanvaarde sekerhede nou onseker geword het en waarin alle konsepte relatief is, omdat dit in 'n voortdurende proses van fluktuasie vasgevang is. Danto (1997:5) verkies om dit eerder kontemporaniteit (contemporaneity) te noem. In 'n postmoderne leefwyse wat deur diversiteit van godsdienstige en morele standpunte gekenmerk word, bevraagteken die gelowige dus tradisionele dogmas, ideologieë en teologieë (Heunis 2008:55). In terme van die kerkmusiek ondersoek musikoloë deesdae eerder die menslike faktor in die akademiese diskoerse, wat dan noodwendig die kwasi-religieuse sekerhede van die modernisme vervang (Butt 2006:10). Daar is dus 'n doelbewuste skuif van 'rede na belewenis, van media na multimedia en van hoor na doen' (Smit 2010:110).

In 'n soeke na antwoorde, spesifiek dié rondom die orrel en musiekbediening, neem baie gemeentes dikwels drastiese stappe sonder om die teologiese en ekklesiologiese gevolge daarvan te bedink (Dawn 2008:2). Die oplossing vir die meeste NG Kerke in Suid-Afrika was om die orrel uit sekere dienste (veral die aanddienste) te verban om sodoende ruimte vir die kontemporêre musiekgees van die tyd te maak (Heunis 2008:57).

\section{Dualistiese denke}

Daar bestaan 'n persepsie dat 'n spesifieke kerkmusiekstyl in die erediens gunstiger as sekulêre musiekstyle is. Laasgenoemde sal dan die erediens onwaardig wees (Strydom 1994:233-234). Vandag behoort die gelowige meer inklusief te dink: In die erediens moet dit nie oor die pyporrel of die musiekbedieningsgroep (band), klassieke musiek of kontemporêre musiek gaan nie. In 'n 
soeke na eerlike aanbidding moet die fokus altyd op die effektiefste manier bly waarop 'n ontmoeting met God en sy heterogene gemeente binne 'n spesifieke kulturele en spirituele konteks gefasiliteer kan word (Strydom pers. komm., Januarie 2014). Richard Rohr (2009) bepleit ook hierdie inklusiewe benadering deur gelowiges op die betekenis van 'en' te wys:

'And' teaches us to say 'yes'. 'And' keeps us from either-or... 'And' is willing to wait for insight and integration. 'And' keeps us from dualistic thinking. 'And' does not divide the field of the moment... 'And' keeps us inclusive and compassionate toward everything... 'And' keeps us from the false choice of liberal or conservative. (pp. 181-182)

\section{'n Bose kringloop}

Bogenoemde faktore vorm 'n bose kringloop wat blootstelling aan goeie en eietydse orrelmusiek verhinder (Kruger pers. komm., November 2013; Olivier 2014).

\section{Pro-aktiewe optrede}

Indien daadwerklike stappe gedoen word, is die situasie nie hopeloos nie. In finansiële terme is die ondersteuning van die beursskema vir orreliste (onder bestuur van SAKOV) verblydend. In 2013 is 'n somtotaal van R625 000 se studiebeursgeld aan orreliste uitgereik (Van Wyk 2014). Die volgende kwelpunte vereis egter verdere aandag.

\section{Opleiding van kerkmusici}

Soos reeds genoem, is die opleiding van orreliste en predikante problematies en studieprogramme sluit dikwels net keusevakke in die Liturgie en Himnologie in. Die totstandkoming van 'n oorhoofse Kerkmusiekinstansie moet indringend ondersoek word (Kruger pers. komm., November 2013). Teologiese studente voltooi hulle studies met min kennis van die Liedboek en kerkliedere. Leerplanne vir toekomstige kerkmusici moet uiteindelik musici oplewer wat in voeling is met die strewe na sinvolle erediensvernuwing (Strydom pers. komm., Januarie 2014).

\section{Die aanstelling van voltydse kerkmusici deur kerkinstansies}

Die kwaliteit van musiek in kerke sal verbeter wanneer musici om gesogte voltydse poste moet meeding. Die skep van sulke voltydse poste sal die aantal studente wat orrel op tersiêre vlak wil studeer, positief beïnvloed (Kruger pers. komm., November 2013). Sulke gesogte poste sal die status van kerkmusici en orreliste in die samelewing en professionele musiekwêreld verhoog (Olivier 2014).

\section{Navorsing in kerkmusiek}

Voortdurende navorsing in kerkmusiek moet aangemoedig word sodat wêreldwye tendense krities ontleed en bespreek kan word (Kruger pers. komm., November 2013).

\section{Opleiding en bemagtiging van die kerkmusikus}

Soos in enige ander beroep behoort die kerkmusikus gereeld op kursusse en simposia gestuur te word om stagnasie te voorkom (Kruger pers. komm., November 2013). Gestandaardiseerde indiensopleiding vir musici uit die 'ou bedeling' is broodnodig om die uitdagings wat vernuwende erediensmusiek bied, te trotseer (Olivier 2014).

\section{Hernude belangstelling}

Die orrel moet relevant bly vir die hedendaagse gehoor. Nuwe denke van geïnspireerde uitvoerders, musikoloë en navorsers moet aangemoedig word (Kruger pers. komm., November 2013). Die pyporrel - miskien meer as enige ander musiekinstrument - het in 'n groot mate vir die hedendaagse jeug irrelevant geword. Orreliste sal vernuwend te werk moet gaan om dié geslag weer in die orrel geïnteresseerd te kry (Theuns pers. komm., Januarie 2014).

\section{Onderhoud en opgradering van instrumente}

Die orrel vereis voortdurende onderhoud en dit het 'n kosteimplikasie vir kerkinstansies. Indien moontlik, behoort swakker instrumente opgegradeer te word (Kruger pers. komm., November 2013).

\section{'n Gesindheidsverandering}

Toegewyde kerkmusici moet besef dat hulle in diens van God is en voortdurend hulle integriteit, motiewe en gesindheid in die lig daarvan ondersoek (Kruger pers. komm., November 2013). Die orrelis moet bereid wees om met ander musiekstyle te waag en om daarmee te eksperimenteer. In Suid-Afrika is daar slegs enkele voorbeelde waar die orrelis daarin slaag om die orrel 'n vars kontemporêre klank te gee (Strydom pers. komm., Januarie 2014).

\section{Gevolgtrekkings oor die Suid- Afrikaanse situasie}

Die orrel is nie meer vanselfsprekend die uitverkore kerkinstrument soos dit in die Afrikaanse gereformeerde kerke van 30 of 40 jaar gelede was nie. Alhoewel dit die gevolg van ' $n$ verskeidenheid faktore is (soos hierbo bespreek), dra die orrelis ook skuld hieraan. Die worship wars aan die einde van die vorige millennium het sommige orreliste as vyandiggesinde musici onthul wat op alternatiewe musiekstyle neerkyk en nie bereid of gemaklik daarmee is om by die effektiewe musiekbediening van verskillende spiritualiteite in die erediens aan te pas nie. ${ }^{12}$

In só 'n geval is die orrel bestem om uit die erediens te verdwyn of net tot 'n erediens te spreek waar die klassieke en/of tradisionele die oorheersende behoefte van die erediensgangers is. Indien die orrel en kerk se verhouding op alle vlakke wil gedy, moet die orrelis bereid wees om

12.Spiritualiteit is 'n komplekse studieveld en dit is nie my doel om in hierdie artikel verder daaroor uit te brei nie. Navorsing toon aan dat erediensgangers elkeen oor ' $n$ unieke spiritualiteit beskik waardeur hulle sin maak van die erediens en oor ' $n$ unieke spiritualiteit beskik waardeur hulle sin maak van die erediens en sy eie geloofslewe (Vos 1996:9). Verdere leesstof oor hierdie onderwerp is ruim beskikbaar, byvoorbeeld die van Cobussen (2008), De Villiers (2006), Dreye (1998), Kourie en Ruthenberg (2008) en Waaijman (2006). Dit is noodsaaklik dat die musiekbediening by die erediensgangers se spiritualiteitstipe 'aanpas'. In laasgenoemde geval verwys ek die leser na 'n artikel in Vir die Musiekleie (Vermeulen 2012a) oor hoe om musiek aan verskillende erediengsgangers met verskillende spiritualiteite te bedien. 
kompromieë aan te gaan en voortdurend aan te pas in die strewe om 'n verantwoordelike musiekbedienaar in die diens van God te wees.

Die verantwoordelikheid lê in 'n groot mate by die orrelis om die gestereotipeerde indrukke van tradisionalisme en konserwatisme rondom die orrel af te breek. Die orrelis dra uiteindelik 'n groot verantwoordelikheid vir die opvoeding van die gemeente en predikante (Strydom pers. komm., Januarie 2014).

\section{Die orrel en kontemporêre musiek}

Die kerkganger met ' $n$ hartspiritualiteit ${ }^{13}$ het 'n affiniteit tot musiek met 'n hoë emosionele inhoud en wil graag deur die musiek meegevoer word. Hierdie spiritualiteitstipe verkies dus musiek waarin hulle hul emosioneel inleef, meegevoer raak en hulle liggaamlik uitdruk. Dit is veral hierdie spiritualiteitstipe wat die orrel as begeleidingsinstrument kritiseer omdat dit nie die musiekbehoeftes van die betrokke spiritualiteitsgroep aanspreek nie (Jankowitz 2006; Ludik s.a.). Die tradisionele kerkorrelis het groot skuld hieraan. Die ouer orrelis met 'n klassieke opleiding weier (of sukkel) dikwels om kontemporêre, toeganklike musiek met sinkope saam met die worship-band te speel. Die jonger orrelis is gewoonlik meer gewillig (of in staat) om in verskillende musiekstyle te musiseer (Kruger pers. komm., November 2013). Dit is 'n ernstige probleem wat aangespreek behoort te word (Campbell 2013:196).

Daar bestaan 'n opvatting dat die orrel nie vir die uitvoer van kontemporêre musiek geskik is nie. In die orrelis se opleiding is daar min tot geen blootstelling aan ander musiekstyle as juis Westerse kunsmusiek nie. Tog, soos vroeër in die artikel genoem, het orrelmusiek effektief aangepas by die musiekstyl en -behoeftes van die dag: van die monofoniese dreunsang in die Middeleeue tot romantiese sonates tot die atonale klanke van Messiaen se musiek.

In die eerste deel van ' $n$ interessante artikel ondersoek Korndörfer (2012:56-59) juis die gebruik van populêre elemente in die orrelmusiek van 1750-1850. Hy kom tot die gevolgtrekking dat prominente orrelkomponiste soos J.S. Bach, Franck, Daquin en Balbastre in die sogenaamde Pastorale $^{14}$ en Franse Noël ${ }^{15}$ probeer het om die orrel aan 'n wyer gehoor bekend te stel deur populêre en sekulêre elemente in die komposisies te inkorporeer. Die werke was baie gewild onder die 'gewone mens', soveel so dat die Aartsbiskop van Parys Balbastre verbied het om Noëls in die erediens te speel aangesien die massas wat deur sy

13. Hartspiritualiteit is een van die vier spiritualiteitstipes wat Ware (1995:39) in haar navorsing onder erediensgangers identifiseer. Aangesien dit nie die doel van hierdie artikel is om spiritualiteit te bespreek nie, word daar met Ware se definisie van hierdie tipe spiritualiteit volstaan: '... it is heart-combined with the concrete real life stuff. Here theology still emphasizes the athropomorphic representation of God and the centrality of scripture, but this is now combined with a more affective, charismatic spirituality whose aim is to achieve holiness of life.'

14.'n Instrumentale komposisie met 'n landelike atmosfeer wat die musiek van skaapwagters naboots (Kennedy 1996:549).

15.Die Noël is ook ' $n$ instrumentale komposisie, hoofsaaklik vir die orrel, wat tydens Kersfees en later by sekulêre konserte uitgevoer is (Kennedy 1996:516). spel aangelok is volgens die Aartsbiskop nie respek vir die kerk gehad het nie (Tobiska 1980:3). In die 19de eeu in Frankryk is die orrelrepertoire aangepas om byval by die kultuur van die dag te vind. Sekulêre komposisies van Franck, Guilmant en Widor is in die erediens gehoor (Ochse 1994:127-128).

Die gebruik van sekulêre musiek in die erediens is ' $n$ teer punt. Strydom (1994:241) en Wolterstorff (1980:84) is van mening dat daar in die erediens eerder van musiek gebruik gemaak moet word wat oor'n spesifieke Woord of evangeliese konnotasie beskik. Volgens hulle kan sekulêre musiek nie sonder verdere kwalifikasie esteties ${ }^{16}$ as 'atmosfeerskepper' vir of tydens die erediens aangewend word nie. Hierdie uitgangspunt blyk effe ouderwets te wees. Loader (2004) stel sy standpunt soos volg:

What moves humans and appeals to them, what stirs and thereby convinces - that is aesthetic and is neither structured in a different way nor functions differently in consciously religious contexts than in others. The essence of the Aesthetical does not mutate according to the circumstance of a particular subject happening to confess to religious contents or not. (pp. 256-257)

Marina Strydom (2005:238) en Evdokimov (1990:10) huldig dieselfde opinie. Indien 'n erediensganger deur middel van musiek nader aan God beweeg, maak dit nie saak of die musiek gewyd of sekulêr van aard is nie. Ons het deel aan God se skoonheid deur'n deelname aan die estetiese.

Die gebruik van die orrel in kontemporêre musiek (soos jazz, pop en rock) wat bes moontlik by erediensgangers met 'n hartspiritualiteit byval sal vind, is nie vergesog nie. Daar is verskeie voorbeelde waar die orrel in moderner idioom gebruik word:

- Die Britse Rock-groep, Yes, gebruik 'n pyporrel in verskeie van hulle albums, onder andere Close to the edge (1972) asook Going for the one (1977).

- Die Amerikaanse Rock-groep, Styx, maak ook in hulle album Pieces of eight (1978) van 'n pyporrel gebruik.

- Die Engelse alternatiewe Rock-groep, Muse, het onlangs 'n pyporrel in hulle album, Origin of Symmetry (2001), gebruik.

- Die Duitse orrelis, Barbara Dennerlein, maak naam in Europa en Amerika as 'n suksesvolle jazz-orrelis.

- Die Amerikaanse orrelis, dr. Carol Williams, maak groot opslae met haar unieke vertolkings van orrelmusiek in klassieke, pop- en rock-idioom. ${ }^{17}$

- Die jong orrelvirtuoos, Cameron Carpenter, vermaak uitverkoopte gehoorsale met klassieke sowel as kontemporêre orrelmusiek.

16. Die 'estetiese' en estetika in die erediens is ' $n$ redelik uitgebreide en komplekse studieveld en daarom word daar spesifiek nie in meer besonderhede daarna verwys nie. Daar bestaan genoeg bronne wat die nut van estetika in die erediens verwys nie. Daar bestaan genoeg bronne wat die nut van estetika in die erediens beredeneer, vernaam die werke van Johan Cillers (2007 en 2012). My eie proefskrif (Vermeulen 2012b) handel ook oor die estetiese musiekbediening van verskillende spiritualiteite in die erediens. Die leser word na hierdie bronne
verwys indien hulle die estetiese begrip in die erediens beter wil verstaan of selfs wil betwis.

17.Meer inligting by http://www.melcot.com 
- Die Hollandse orrelis, Klaas-Jan Mulder, het veral in die 1980's groot sukses met sy crossover-musiekgroep genaamd KAJEM behaal.

\section{'n Toekomsperspektief}

Orreliste moet bereid wees om te eksperimenteer en vernuwend te dink. Die pyporrel is een van die veelsydigste instrumente en dit kan met vrug in bykans enige musiekstyl gebruik word. Die orrel het oor 'n tydperk van nagenoeg 1000 jaar suksesvol by die kultuur van die dag aangepas en daar is geen rede waarom die orrel nie in byderwetse se moderne musiekstyle soos jazz, pop en rock effektief benut kan word nie. Indien die groot kerkmusikus J.S. Bach populêre elemente in sy komposisies kon gebruik, is daar nie rede waarom die hedendaagse kerkorrelis nie ook kan nie, in stede daarvan om skouers (en neus) vir enige populêre musiekgenre op te trek. Dit beteken dat die orrel nie sonder meer in 'n kontemporêre erediens ${ }^{18}$ oorbodig verklaar moet word nie. Die orrelis kan nou die rol van orkeslid (of band member) inneem. Dit beteken dat musiek des te meer verwerk, beplan en ingeoefen behoort te word. ${ }^{19}$

\section{Vinjet 2}

Theuns kyk na 'n YouTube clip op sy iPad. Sy meisie het vandag die link vir hom ge-forward.

In die clip tree Muse in 2008 in die Royal Albert Hall op. Matthew Bellamy, die lead singer van dié Engelse rockband, stap na die groot konsert-orrel toe.

'Since we're playing in the Albert Hall, I thought it would be rude not to play this beast,' sê hy en begin 'n paar akkoorde op die pyporrel speel. Die gehoor raak mal.

Dan begin hy met die inleiding tot Megalomania en die band val saam met hom in. Die skare juig en gooi hulle hande in die lug. Helder beligtingstrale flits oor die verhoog en die orrelpype terwyl Matthew sing: 'Paradise comes at a price ...'

Nádat die laaste, forse akkoorde van die orrel aan die einde van die lied weergalm het, klink die dawerende waardering van die gehoor vir etlike minute.

Een van die duisende fans se comments op die YouTube link lees soos volg:

'I love to see Matt playing sucha [sic] great pipe organ. He's usually more of a rockstar, but when he walked up to that organ he seemed so fascinated by how awesome it was, and then he

18. In die kontemporêre erediens word kontemporêre musiek gebruik omdat die erediensgangers die pyporrel as ouderwets ervaar. Die gang van die liturgie is vinnig, daar word minder van stiltes gebruik gemaak en die erediensganger se sintuiglike waarneming word deur die afwisseling van verskillende klanke en beelde sintuiglike waarneming word deur die afwisseling van verskillende klanke en beelde gestimuleer. Die voorsangers en musiekgroep (of band) speel ' $n$ meer leidende rol in die verkondiging van die boodskap, sowel as in die atmosfeer wat tydens die diens geskep word. Erediensgangers met 'n hartspiritualiteit sal waarskynlik hier
tuis voel (Engelbrecht 2008).

19.In 'n moontlike opvolgartikel kan die aanwending van die orrel in 'n populêre idioom of sogenaamde kontemporêre musiek prakties toegelig word. Om hierdie rede word dit nie verder in hierdie artikel bespreek nie. just started playing it and you realize there's more to him than just one music genre.'

'Wow', sê Theuns aan die einde van die clip, 'Hoe amazing is dit?'

\section{Slot}

Die orrel is die oudste klawerbordinstrument op aarde en het 'n ryke geskiedenis van ontwikkeling en aanpassing. Die kerk en hierdie veelsydige instrument het reeds in $900 \mathrm{nC}$ 'n lang pad as liturgiese vennote begin stap. Uit die geskiedenis leer ons dat hierdie verhouding dikwels stormagtig was en soms op die rand van 'n egskeiding gehuiwer het. Die verhouding kan daarom as 't ware as 'n huwelik beskryf word: In good times and in bad, om die Engelse huweliksformulier aan te haal.

Die kere wat hierdie verhouding gedreig het om te ontbind (soos onder andere in die Reformasie, Engeland teen 1640 en Frankryk ca. 1789) was dit hoofsaaklik aan 'n ongegronde oorreaksie teen bestaande praktyke te wyte en daarom het die verhouding na verloop van tyd weer herstel. Albei partye het egter deurentyd veranderings ondergaan en aangepas.

Die verhouding in Suid-Afrika is vandag kommerwekkend. Die orrel word as 'n randfiguur uitgeskuif en daarvan beskuldig dat dit outyds is en nie meer tot die erediensganger se musikale behoeftes spreek nie. Hoewel daar 'n verskeidenheid redes aangevoer kan word, is die orrelis gedeeltelik hiervoor verantwoordelik. Die worship wars van die 1980's onthul 'n onbuigsame en dikwels ongenaakbare orrelis wat sy musiekbehoeftes en -style as die enigste geskikte kerkmusiekstyl wil afdwing.

Die ontwikkeling van die spiritualiteit-studieveld toon aan dat erediensgangers oor verskillende musiekbehoeftes beskik wat nie noodwendig deur die klassieke orrelstyl aangespreek word nie. Om dié rede word die pyporrel dikwels nie tydens kontemporêre eredienste gehoor nie.

Daar is egter geen rede waarom die pyporrel nie met vrug in sulke eredienste aangewend kan word nie. Daar is genoegsame bewyse om aan te toon dat die orrel vernuwend en in populêre musiekstyle gebruik kan word. Om hierdie ou instrument vernuwend in 'n vrugtevolle musiekbediening in die erediens aan te wend, verg egter inspanning en navorsing.

Solank die orrelis weier om kompromieë aan te gaan, is hierdie huwelik, soos met enige ander verhouding in dieselfde situasie, bes moontlik tot egskeiding gedoem. Ook in terme van musiekbediening is die beginsel van diversiteit en verdraagsaamheid van uiterste belang.

\section{Erkenning}

Die outeur erken hiermee, met dank, die insig en inspirasie van proff. Bertha Spies en Hetta Potgieter met die skryf van hierdie artikel. 


\section{Mededingende belange}

Die outeur verklaar hiermee dat hy geen finansiële of persoonlike verbintenis het met enige party wat hom nadelig of voordelig kon beïnvloed het in die skryf van hierdie artikel nie.

\section{Verwysings}

Basson, W.D., 1997, 'Die liturgiese funksie van die orrel in die gereformeerde erediens met spesifieke verwysing na die N.G. Kerk in Suid-Afrika', M.Mus.-verhandeling, Departement Musiek, Universiteit van Stellenbosch.

Bennet, R., 1985, Keyboard instruments, University Press, Cambridge.

Blume, F., 1974, Protestant church music, George J. McLeod, Toronto.

Butt, J., 2006, 'The postmodern mindset, musicology and the future of the Bach scholarship', Understanding Bach 1(Maart), 9-18.

Campbell, C.A., 2013, 'Music ministry in the missional worship service in the Dutch Reformed Church in South Africa', Ph.D. proefskrif, Skool vir Musiek, NoordwesUniversiteit.

Cilliers, J., 2007, Binne die kringdans van die kuns: Die betekenis van estetika vir die gereformeerde erediens, Sun Press, Stellenbosch.

Cilliers, J., 2012, Dancing with deity: Re-imagining the beauty of worship, Bible Media, Wellington.

Cobussen, M., 2008, Thresholds: Rethinking spirituality through music, Ashgate Hampshire.

Dawn, M.J., 2008, 'Worship for postmodern times', Federation of Diocesan Liturgical Commissions Newsletter 35(1), 1-8.

De Villiers, P.G.R., 2006, 'Preface', Acta Theologica Supplementum 8, i-v. http://dx.doi org/10.1017/CBO9780511494857.001

Dreyer, T.F.J., 1998, 'Die akkommodering en bestuur van diversiteit in gemeenteverband', Hervormde Teologiese Studies 62(4), 1291-1309.

Du Toit, H., 1979, Popmusiek as kerkmusiek? Oorwegings by die vernuwing van die kerklied, NG Kerkboekhandel, Pretoria.

Engelbrecht, F., 2008, 'Kontemporêre aanbiddingstyl', in Aanbiddingstyle in praktyk van die NG Kerk, DVD, Bybel-Media, Kaapstad.

Evdokimov, P., 1990, The art of the icon: a theology of beauty, Oakwood Publications, Torrance.

Feder, G., 1974, 'Decline and restoration', in F. Blume (red.), Protestant church music, pp. 317-404, George J. McLeod, Toronto.

Gwynn, D., 2003, 'Out of a chance survival', Choir \& Organ 11(5), 74-78.

Herl, J., 2004, Worship wars in early Lutheranism, Oxford University Press, New York.

Heunis, S., 2008, 'Die liturgiese gebruik van die orrel in 'n post-mordene era: Persepsies van kerkmusici en leraars van die Nederduitse Gereformeerde gemeentes in Port Elizabeth', M.Mus.-verhandeling, Departement Musiek, Nelson Mandela Metropolitan University.

Higginbottom, E., 1998, 'Organ music and the liturgy', in N. Thistlethwaite \& G Webber (reds.), The Cambridge companion to the organ, pp. 130-147, Cambridge University Press, Cambridge.

Ingelse, C., Van Laar, J.D., Sanderman, D. \& Smelik, J. (reds.), 1995, Nieuw handboek voor de kerorganist, Uitgeverij Boekenventrum, Zoetemeer.

Jackson, N., 2006, "n NG Kerk sing populêre liedere ook', Die Burger, 03 Maart, bl. 3.

Jankowitz, D., 2006, 'Die musiekleier as bedienaar van verskillende spiritualiteitstipes in 'n eietydse gereformeerde erediens', Vir die Musiekleier 33, 30-39.

Janse van Rensburg, J., 1995, 'Perspektiewe op 'n kontemporêre gereformeerde bediening', In die Skriflig 29(4), 623-644. http://dx.doi.org/10.4102/ids.v29i4.1557

Kennedy, M. (red.), 1996, The Oxford concise dictionary of music, 4de uitg., Oxford University Press, Oxford.

Kloppers, E.C., 2002b, 'Die kreatiewe inrigting van die liturgie', Vir die Musiekleier 29 $12-18$.

Kloppers, E.C., 2003a, 'Verkondiging deur musiek: 'n Aspek van kreatiewe geloofskommunikasie', HTS Teologiese Studies/Theological Studies 59, 65-84. http://dx.doi.org/10.4102/hts.v59i1.648
hel

Kloppers, E.C., 2003b, 'Die invloed van 'n postmoderne tydsgees op die kerklied: Enkele rigtingwysers', Nederduitse Gereformeerde Teologiese Tydskrif 44(3\&4) 320-329.

Kloppers, E.C., 2003c, 'Postmodernisme, nostalgie en die himniese geheue', STILET $15(2), 200-217$

Kloppers, E.C., 2005, 'Handelinge in die erediens: Die verryking van die liturgie deu musiek', HTS Teologiese Studies/Theological Studies HTS 61(1/2), 191-207.

Kloppers. E.C., 2002a, 'Transendering van die alledaagse: Die erediens as fees', Praktiese Teologie in Suid-Afrika 17(2), 61-74.

Korndörfer, J., 2012, 'Secular or sacred: Selected popular elements in organ music: Part I', The American Organist 46(6), 56-59.
Kourie, C. \& Ruthenberg, T., 2008, 'Contemporary Christian spirituality: An "encompassing field"', Acta Theologica Supplementum 11, 76-93.

Kruger, D., 2007, 'A high degree of understanding and tolerance: Veranderende denke oor die hedendaagse kerkmusiek, Vir die Musiekleier 28, 14-24.

Loader, J.A., 2004, 'Theologies as symphonies: On (biblical) theologies and aesthetics', Old Testament Essays 17(2), 252-266.

Long, K.R., 1971, The music of the English Church, St. Martin's, New York.

Ludik, B., s.a. Vier tipes spiritualiteit, besoek op 02 Maart 2013, by http://www. nglangenhovenpark.org.za

McKinnon, J., 1998, The ministry of musicians, Liturgical Press, Collegeville.

Ochse, O., 1994, Organists and organ playing in nineteenth-century France and Belgium, Indiana University Press, Bloomington.

Olivier, G., 2014, E-pos, 08 Januarie 2014.

Ponsford, D., 2011, French organ music in the reign of Louis XIV, University Press, Cambridge.

Ritchie, G. \& Stauffer, G.B., 1992, Organ technique: Modern and early, Prentice Hall, Upper Saddle River.

Rohr, R., 2009, The naked now: Learning to see as the mystics see, The Crossroad Publishing Company, New York.

Rumsey, D., 1978, Medieval organ culture to the 15th century, an overview, vert. Patricia Fitzsimmons, besoek op 20 Mei 2014, by http://www.davidrumsey.ch/ Medieval\%20organ\%20culture.pdf

Ryves, B., 1685, Mercurius Rusticus: Or, the countries' complaint of the sacrileges, prophanations, and plunderings, committed by die Sachismatiques, on the cathedral churches of this kingdom, Richard Green, Londen.

Serfontein, A., 2005, 'Lof en aanbidding: Vernuwing in hoofstroom kerke', Kruisgewys $5(1), 21-22$.

Smit, E.J., 2010, 'Enkele aspekte met betrekking tot die gereformeerde erediens en kerklied in 'n multikulturele Suid-Afrika', In die Skriflig 44(1), 99-119. http:// dx.doi.org/10.4102/ids.v44i1.139

Strydom, M., 2005, 'Vyf dogters van Eva skilder'n engel: Die gebruik van terapeutiese kuns in die uitlewing van spirituele identiteit by die jong volwasse vrou', D.Phil.proefskrif, Departement Praktiese Teologie, Universiteit van Pretoria.

Strydom, W.M.L., 1994, 'Sing nuwe sange, nuutgebore': Liturgie en lied, Universiteit van die Oranje-Vrystaat, Departement Musiek (Afdeling Kerkmusiek) Bloemfontein.

Swanepoel, I., 2014, Die effektiewe benutting van die orrel in die liturgie van die hedendaagse Nederduitse Gereformeerde Kerk, M.Mus.-verhandeling, Skool vir Musiek, Noordwes-Universiteit.

Tobiska, J.S., 1980, 'The Noels of the eighteenth-century French School', D.Mus. thesis, School of Music, University of Washington.

Troskie, A., 1992, Pyporrels in Suid-Afrika, J.L. van Schaik, Pretoria.

Troskie, A., 2010, The pipe organ heritage of South Africa, Albert Troskie, Port Elizabeth.

Troskie, A., 2013, 'Die pyporrel: Vir twee eeue die draer van Westerse musiekkultuur in Suid-Afrika', Vir die Musiekleier 33, 83-91.

Van Wyk, T., 2014, E-pos, 21 Februarie 2014.

Vermeulen, O.C., 2012a, 'Estetiese musiekbediening in die Afrikaanse gereformeerde erediens: Die rol van spiritualiteit en inligtingsteorie', Vir die Musiekleier 32, 1-15.

Vermeulen, O.C., 2012b, 'Vernuwende gebruik van die orrel in 'n estetiese musiekbediening van verskillende spiritualiteitstipes in die Afrikaanse gereformeerde erediens', D.Mus.-proefskrif, Departement Musiek, Universiteit van Pretoria.

Viljoen, M., 1999, 'Die tweeslagtige kerksangpraktyk van die Nederduitse Gereformeerde Kerk: 'n Historiese perspektief op die eietydse vraagstuk', Acta Academica 31(3), 94-126.

Viljoen, W., 2014, E-pos, 08 Januarie 2014.

Vos, C.J.A., 1996, Die volheid daarvan: Homiletiek uit'n hermeneuties-kommunikatiewe perspektief: Vol. I. RGN, Pretoria.

Waaijman, K., 2006, 'What is spirituality?', Acta Theologica Supplementum, 8 1-18.

Ware, C., 1995, Discover your spiritual type: A guide to individual and congregation growth, Alban Institute, New York.

Williams, P. \& Owen, B., 1980, Organ, MacMillan Press, Londen.

Williams, P., 1966, The European organ, 1450-1850, B.T. Batsford, Londen

Williams, P., 1980, A new history of the organ, Faber and Faber, Londen.

Williams, P., 1993a, The king of instruments, Cromwell Press, Londen.

Williams, P., 1993b, The organ in western culture, 750-1250, University Press, Cambridge.

Williams, P., 1993c, The king of instruments: How churches came to have organs, SPCK, Londen.

Williams, P., 2003, The organ music of J.S. Bach, 2 de uitg., University Press, Cambridge. http://dx.doi.org/10.1017/CB09780511481871

Wolterstorff, N., 1980, Art in action: Toward a Christian aesthetic, Eerdmans, Grand Rapids.

Yudkin, J., 1989, Music in Medieval Europe, Prentice Hall, New Jersey. 